\title{
Feeding and production of the carnivorous copepod Pareuchaeta norvegica in the Skagerrak
}

\author{
Kajsa Tönnesson ${ }^{1,2}$, Torkel Gissel Nielsen ${ }^{2}{ }_{\text {Peter Tiselius }}{ }^{1, *}$ \\ ${ }^{1}$ Department of Marine Ecology, Göteborg University, Kristineberg Marine Research Station, 45034 Fiskebäckskil, Sweden \\ ${ }^{2}$ National Environmental Research Institute, PO Box 359, 4000 Roskilde, Denmark
}

\begin{abstract}
The vertical and horizontal distribution of the carnivorous copepod Pareuchaeta norvegica Boeck and its potential prey were analysed in the Skagerrak during spring 1999 and autumn 2000. Feeding by P. norvegica was assessed by measuring egestion of faecal pellets. Pellet production at night was significantly higher than during the day. Feeding rates for females ranged from 1.4 to 5.2 prey $\mathrm{d}^{-1}$ in the spring and from 6.2 to 8.6 prey $\mathrm{d}^{-1}$ in the autumn. Feeding rates for juveniles were higher in both seasons. Peak spermatophore attachment and fertilisation occurred during spring when the proportion of males was also highest. The weight-specific egg production rate was estimated by the egg ratio method and ranged from 0.31 to $0.73 \% \mathrm{~d}^{-1}$ in the spring and from 0.42 and $0.66 \% \mathrm{~d}^{-1}$ in the autumn; no significant difference between seasons was found. The number and the total volume of the eggs were positively correlated to prosome length of the females. The population of $P$. norvegica ingested 2.0 to $4.6 \%$ of the spring copepod population daily and 2.4 to $6.5 \%$ of the autumn population. The predation impact of $P$. norvegica was equivalent to 6 to 14 and 9 to $16 \%$ of the copepod population production in spring and autumn, respectively, illustrating the importance of this species in the Skagerrak pelagic ecosystem. Compared with the other important invertebrate predators, the chaetognaths, the impact of $P$. norvegica was 10 to 100 times higher in both seasons.
\end{abstract}

KEY WORDS: Pareuchaeta norvegica $\cdot$ Reproductive biology $\cdot$ Feeding $\cdot$ Temperature

\section{INTRODUCTION}

The large carnivorous copepod Pareuchaeta norvegica Boeck has its main distribution in the North Atlantic Ocean, predominately in offshore areas, but also in some of the deeper Scottish, Swedish and Norwegian fjords (Bakke 1977, Park 1995, Dale et al. 1999). $P$. norvegica is a tactile predator and detects the hydrodynamic disturbances of moving prey by cruising in search of it (Greene \& Landry 1985, Greene 1988, Yen 1982a, 1987, 1988). Large prey are held by the maxillae and maxillipeds and moved to the mouth. Only parts of large prey are consumed, the rest being discarded. $P$. norvegica preys on small copepods (Lowndes 1935, Båmstedt \& Holt 1978, Kaartvedt et al. 2002) and may occur in substantial numbers that potentially make it an important actor in the pelagic food web. Studies have shown that $P$. norvegica may also be an important predator on larger copepods, e.g. Calanus finmarchicus (Bathmann et al. 1990, Bagøien 1999) and cod larvae (Yen 1987).

Most species of pelagic calanoid copepods are broadcast spawners, i.e. they release their eggs into the sea while others, like Pareuchaeta norvegica, carry their eggs until hatching. It is generally agreed that the number of eggs produced by the female is associated with the degree of parental care, i.e. species that protect their eggs by carrying them tend to lay fewer and larger eggs, relative to the size of the female, than freespawning copepod species (Kiørboe \& Sabatini 1995).

The present investigation was conducted during the spring diatom bloom and in early autumn. The spring bloom represents the most intense period of primary production, while autumn is the culmination of the het- 


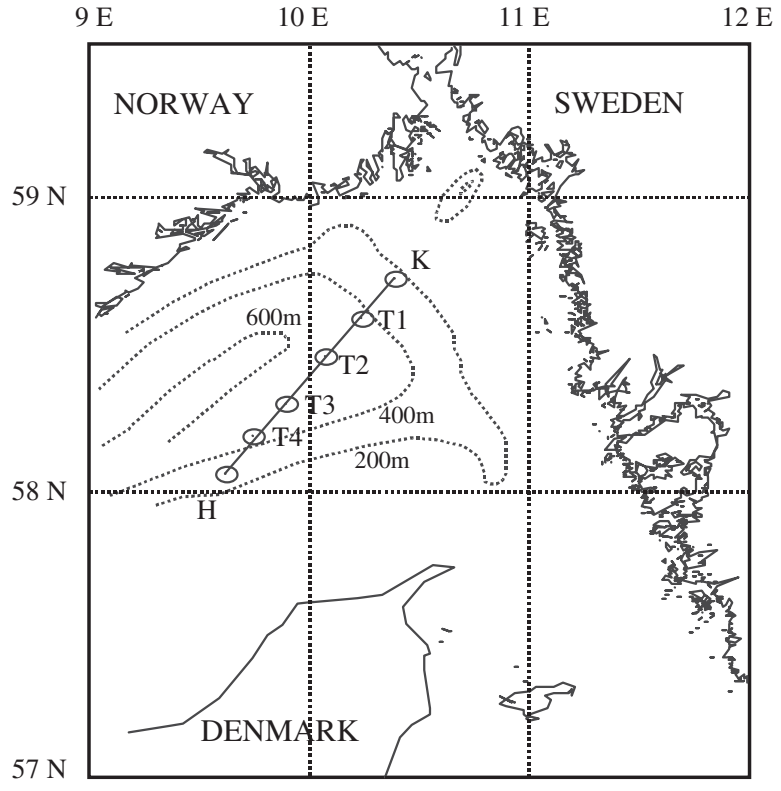

Fig. 1. Map of the Skagerrak showing sampling stations
Abundance. The abundance of Pareuchaeta norvegica and its prey in the upper $100 \mathrm{~m}$ was quantified using a submersible pump (1.2 $\left.\mathrm{m}^{3} \mathrm{~min}^{-1}\right)$ equipped with a $45 \mu \mathrm{m}$ net. $P$. norvegica is a deep living copepod, but we were mainly interested in its predation impact on the copepod community in the upper $100 \mathrm{~m}$. In the spring, the Koster and Hirtshals stations were sampled at 5 depth strata: $0-10,10-25,25-40,40-60$ and 60-100 m, while only 2 strata, $0-25$ and $25-100 \mathrm{~m}$ were sampled on the transect stations. In the autumn, 5 depth strata were sampled at all stations: 0-10, 10-25, 25-40, 40-60 and 60-100 m. At 5 stations (in autumn), additional sampling with a WP-2 net (mesh size $200 \mu \mathrm{m}$ ) was conducted. After collection, the samples were concentrated on a $30 \mu \mathrm{m}$ sieve and fixed in $2 \%$ buffered formalin (final concentration). In the laboratory, $P$. norvegica and prey copepods (excluding nauplii) were counted and their lengths measured. The number of females carrying eggs and detached egg sacs were counted.

Experiments. Animals for experiments (Table 1) were obtained either from $20 \mathrm{~min}$ oblique hauls ( 0 to erotrophic pelagic cycle where the zooplankton biomass peaks. The fate of primary production depends on the match-mismatch between phytoplankton growth and zooplankton grazing pressure. Current knowledge on the role of predation in zooplankton population dynamics is very limited.

In this study, we examined the role of Pareuchaeta norvegica in the pelagic ecosystem through investigation of vertical distribution, feeding, gut evacuation time, chemical composition and egg production in the Skagerrak during spring 1999 and autumn 2000.

\section{MATERIALS AND METHODS}

The investigations were carried out from RV 'Dana' (Danish Institute of Fisheries Research) from 20 to 28 March 1999 and from 25 August to 3 September 2000 at 6 stations across the Skagerrak (Fig. 1). The 2 periods will be referred to as spring and autumn, respectively. The investigations included 2 intensively sampled stations, Koster Station (K) and Hirtshals Station $(\mathrm{H})$; and 4 less intense transect stations (Stn T1 to T4). Profiles of temperature, salinity and fluorescence were measured continuously from the surface to between 100 and $300 \mathrm{~m}$ on each sampling occasion; all basic oceanographic data are presented elsewhere (Maar et al. 2002, 2004).
Table 1. Pareuchaeta norvegica. Station, date and time of experiments conducted in the study

\begin{tabular}{|c|c|c|c|c|}
\hline Station & Date & $\begin{array}{c}\text { Time } \\
(\mathrm{h})\end{array}$ & Experiment & $\begin{array}{c}\text { No. of } \\
\text { animals }\end{array}$ \\
\hline \multicolumn{5}{|l|}{ Spring } \\
\hline $\mathrm{K}: 1$ & 21 Mar 99 & 06:00 & Faecal pellet production & 24 \\
\hline $\mathrm{K}: 2$ & 23 Mar 99 & 06:00 & $\begin{array}{l}\text { Faecal pellet production } \\
\text { Egg hatching }\end{array}$ & $\begin{array}{l}36 \\
10\end{array}$ \\
\hline $\mathrm{T} 2: 1$ & 23 Mar 99 & $12: 00$ & $\begin{array}{l}\text { Faecal pellet production } \\
\text { Egg hatching } \\
\text { Gut evacuation }\end{array}$ & $\begin{array}{l}18 \\
12 \\
70\end{array}$ \\
\hline $\mathrm{T} 2: 2$ & 24 Mar 99 & 04:00 & Faecal pellet production & 20 \\
\hline $\mathrm{T} 4: 1$ & 23 Mar 99 & 20:00 & $\begin{array}{l}\text { Faecal pellet production } \\
\text { Egg hatching }\end{array}$ & $\begin{array}{r}24 \\
8\end{array}$ \\
\hline $\mathrm{T} 4: 2$ & 24 Mar 99 & 09:00 & Faecal pellet production & 20 \\
\hline $\mathrm{H}: 1$ & 26 Mar 99 & 04:00 & $\begin{array}{l}\text { Faecal pellet production } \\
\text { Egg hatching } \\
\text { Gut evacuation }\end{array}$ & $\begin{array}{l}20 \\
10 \\
80\end{array}$ \\
\hline $\mathrm{H}: 2$ & 26 Mar 99 & $16: 00$ & Faecal pellet production & 24 \\
\hline \multicolumn{5}{|l|}{ Autumn } \\
\hline K & 26 Aug 00 & 20:00 & Faecal pellet production & 14 \\
\hline $\mathrm{T} 2: 1$ & 28 Aug 00 & $24: 00$ & $\begin{array}{l}\text { Faecal pellet production } \\
\text { Gut evacuation } \\
\text { Egg hatching }\end{array}$ & $\begin{array}{l}44 \\
62 \\
10\end{array}$ \\
\hline $\mathrm{T} 2: 2$ & 29 Aug 00 & $14: 00$ & $\begin{array}{l}\text { Faecal pellet production } \\
\text { Gut evacuation } \\
\text { Egg hatching }\end{array}$ & $\begin{array}{l}42 \\
58 \\
12\end{array}$ \\
\hline Т3 & 01 Sep 00 & $14: 00$ & $\begin{array}{l}\text { Faecal pellet production } \\
\text { Egg hatching }\end{array}$ & $\begin{array}{l}12 \\
12\end{array}$ \\
\hline $\mathrm{T} 4$ & 31 Aug 00 & $24: 00$ & $\begin{array}{l}\text { Faecal pellet production } \\
\text { Egg hatching }\end{array}$ & $\begin{array}{l}18 \\
10\end{array}$ \\
\hline
\end{tabular}


$50 \mathrm{~m}$ ) with a MIK trawl (mesh size = $1 \mathrm{~mm}$, aperture diameter $=2 \mathrm{~m}$ ) or vertical hauls using a WP-2 net (mesh size $=200 \mu \mathrm{m}$ ) in spring and vertical hauls with a plankton net (mesh size $=45 \mu \mathrm{m})$ with a $301 \mathrm{cod}$ end in autumn. Water for incubation was collected from $5 \mathrm{~m}$ using a Niskin bottle and screened through a net (mesh size $=45 \mu \mathrm{m})$ to remove prey. Subsamples were concentrated on a $30 \mu \mathrm{m}$ sieve and fixed in $2 \%$ buffered formalin (final concentration) to analyse the number of spermatophores.

Gut content. Feeding was assessed by measuring egestion of faecal pellets since experimental studies have shown a linear relationship between food intake and the number of pellets defecated (Yen 1987, 1991, Tiselius et al. 1997, Olsen et al. 2000). Although the food might have an effect on the quantity of pellet material (Yen 1987, Kaartvedt et al. 2002), we assumed 1 pellet = 1 small copepod prey. Olsen et al. (2000) found 0.5 prey pellet ${ }^{-1}$ and Tiselius et al. (1997) reported 0.77 prey pellet ${ }^{-1}$. However, in both of these studies, pellets were collected at the same time as remaining prey copepods. Given the long digestive time of Pareuchaeta norvegica, these ratios are underestimates. As the digestive time was $21 \mathrm{~h}$ at $5^{\circ} \mathrm{C}$ and $12.5 \mathrm{~h}$ at $15^{\circ} \mathrm{C}$ (see Fig. 5), Tiselius et al. (1997) suggested that $24 \mathrm{~h}$ incubations of previously starved animals would seriously underestimate pellet production. We followed their experience of 1 pellet being formed per prey.

The content of the cod end was transferred to a thermo box with surface water and immediately brought to the laboratory. Within $1 \mathrm{~h}$ of collection, individual Pareuchaeta norvegica females or copepodites were pipetted (wide bore pipette) into $50 \mathrm{ml}$ plastic centrifuge tubes filled with pre-screened $(45 \mu \mathrm{m})$ water from a depth of $5 \mathrm{~m}$. The tubes were then filled up, sealed with film and incubated in darkness at $5^{\circ} \mathrm{C}$ (in spring) and at $15^{\circ} \mathrm{C}$ (in autumn) for approximately $48 \mathrm{~h}$. At the end of the incubations, the content was gently poured through a $90 \mu \mathrm{m}$ sieve to collect animals and faecal pellets. The length of females or copepodites and the dimensions of the pellets were measured using a dissection microscope.

Gut evacuation. Within $1 \mathrm{~h}$ of collection, 10 females were gently transferred with a wide bore pipette to $620 \mathrm{ml}$ blue cap incubation bottles containing $45 \mu \mathrm{m}$ filtered seawater. The bottles were filled up and incubated in darkness in a cold room at in situ surface temperature $\left(5^{\circ} \mathrm{C}\right.$ in spring and $15^{\circ} \mathrm{C}$ in autumn) for $48 \mathrm{~h}$ complete gut evacuation to be reached. Every 30 to $120 \mathrm{~min}$, the animals were transferred to a new bottle and the bottle content was gently poured through a $90 \mu \mathrm{m}$ sieve to collect pellets.

The gut evacuation rate $\left(R, \mathrm{~h}^{-1}\right)$ was determined by a regression of the number of pellets remaining in the guts of 10 to 11 animals in each bottle against time. The number of remaining pellets at time t $\left(P_{t}\right)$ was estimated as:

$$
P_{t}=P_{\text {tot }}-\sum_{t=0}^{t} P
$$

where $P_{\text {tot }}$ is the total number of pellets produced in an incubation and $\sum_{t=0}^{t} P$ the cumulative number of pellets collected at time $t$. $R$ is the slope of the regression.

The feeding rate $\left(F R_{\mathrm{h}}\right.$, prey $\left.\mathrm{h}^{-1}\right)$ was calculated separately for day and night as:

$$
F R_{\mathrm{h}}=N P \times R
$$

where $N P$ is the number of prey (assuming 1 pellet $=1$ prey) per copepod and $R$ is the gut evacuation rate $\left(\mathrm{h}^{-1}\right)$. We then estimated the daily feeding rate $(F R$, prey $\mathrm{d}^{-1}$ ) using the mean value of the night and day values.

Egg hatching. Females carrying egg sacs from 0 to $50 \mathrm{~m}$ were placed individually in 6 -well tissue culture trays (NUNCLON ${ }^{\mathrm{TM}}$ Multi wells) containing $17 \mathrm{ml}$ of $45 \mu \mathrm{m}$-filtered seawater and incubated at constant temperature $\left(5^{\circ} \mathrm{C}\right.$ in spring and $15^{\circ} \mathrm{C}$ in autumn) for $14 \mathrm{~d}$. Every $12 \mathrm{~h}$, nauplii and undeveloped eggs were counted and their respective proportion calculated. Hatching percentage was calculated from the number of clutches hatched divided by the number of females incubated. The hatching rate $(H R)$ then was calculated from the slope of the cumulative hatching percentage plotted against time. The population-specific egg production rate $\left(S E P\right.$, egg female ${ }^{-1} \mathrm{~d}^{-1}$ ) was estimated by the egg-ratio method (Edmondson 1971)

$$
S E P=(\text { egg/female }) \times H R \times(\text { egg } \mathrm{C} / \text { female } \mathrm{C})
$$

where egg/female is the egg:female ratio of the population (including females not carrying eggs and detached egg sacs), $H R\left(\mathrm{~d}^{-1}\right)$ the egg hatching rate at in situ temperature and egg $\mathrm{C} /$ female $\mathrm{C}$ the ratio of egg to female carbon. The hatching time is defined as the time required to reach $100 \%$ hatching predicted from the regression between the cumulative hatching percentage and the time.

Some egg sacs were detached from females during collection and preservation. Detached egg sacs were counted and the egg:female ratio adjusted accordingly. The egg dry weight was calculated from Nemoto et al. (1976). The average dry weight of an egg mass was $0.60 \mathrm{mg}$ and the average number of eggs in an egg mass was 30, giving a value for average egg dry weight of $20 \mu \mathrm{g}$ (Nemoto et al. 1976). Carbon content was calculated from the carbon to egg dry weight ratio (approximately $63 \%$ ) in Nemoto et al. (1976).

Length-weight regressions. Within $1 \mathrm{~h}$ of collection, copepods were deep frozen $\left(-20^{\circ} \mathrm{C}\right)$ for later analyses in the laboratory. Different stages of copepods were individually washed in $0.2 \mu \mathrm{m}$-filtered seawater, mea- 
Table 2. Pareuchaeta norvegica. Abundance of potential prey (ind. $\mathrm{m}^{-3}$ ) for P. norvegica in (A) spring 1999 and (B) autumn 2000. Calanus sp.: Cal.; Paracalanus sp.: Par.; Pseudocalanus spp.: Pseu.; Microcalanus spp.: Mic.; Temora spp.; (Tem.); Acartia spp.: Ac.; Oithona spp.: Oith.; Centropages sp.: Cent.; Corycaeus sp.: Co.; Microsetella sp.: Micr.; total small copepod prey (not Calanus sp.): Total. Numbers within parentheses refer to the average size $(\mu \mathrm{m})$ of each species

\begin{tabular}{|c|c|c|c|c|c|c|c|c|c|c|c|}
\hline $\begin{array}{l}\text { (A) } \\
\text { Station }\end{array}$ & Depth & $\begin{array}{l}\text { Cal. } \\
(1810)\end{array}$ & $\begin{array}{l}\text { Par. } \\
(510)\end{array}$ & $\begin{array}{l}\text { Pseu. } \\
(560)\end{array}$ & $\begin{array}{l}\text { Mic. } \\
(440)\end{array}$ & $\begin{array}{l}\text { Tem. } \\
(890)\end{array}$ & $\begin{array}{l}\text { Ac. } \\
(700)\end{array}$ & $\begin{array}{l}\text { Oith. } \\
(400)\end{array}$ & $\begin{array}{l}\text { Cent. } \\
(690)\end{array}$ & $\begin{array}{l}\text { Micr. } \\
(460)\end{array}$ & Total \\
\hline $\begin{array}{l}\text { K:1 } \\
21 \text { Mar 99, 06:00 h }\end{array}$ & $\begin{array}{c}0-10 \\
10-25 \\
25-40 \\
40-60 \\
60-100\end{array}$ & $\begin{array}{r}214 \\
168 \\
32 \\
5 \\
18\end{array}$ & $\begin{array}{r}6 \\
45 \\
9 \\
1 \\
2\end{array}$ & $\begin{array}{r}1483 \\
84 \\
19 \\
6 \\
24\end{array}$ & $\begin{array}{r}110 \\
134 \\
1082 \\
127 \\
276\end{array}$ & $\begin{array}{r}184 \\
10 \\
0 \\
1 \\
0\end{array}$ & $\begin{array}{r}159 \\
5 \\
0 \\
0 \\
1\end{array}$ & $\begin{array}{r}655 \\
1054 \\
185 \\
26 \\
42\end{array}$ & $\begin{array}{r}86 \\
0 \\
0 \\
0 \\
2\end{array}$ & $\begin{array}{r}257 \\
638 \\
605 \\
76 \\
57\end{array}$ & $\begin{array}{r}2940 \\
1979 \\
1919 \\
237 \\
404\end{array}$ \\
\hline $\begin{array}{l}\text { K:2 } \\
22 \text { Mar 99, 06:00 h }\end{array}$ & $\begin{array}{c}0-10 \\
10-25 \\
25-40 \\
40-60 \\
60-100\end{array}$ & $\begin{array}{r}247 \\
592 \\
0 \\
3 \\
2\end{array}$ & $\begin{array}{r}0 \\
49 \\
9 \\
6 \\
1\end{array}$ & $\begin{array}{r}898 \\
274 \\
6 \\
12 \\
11\end{array}$ & $\begin{array}{r}12 \\
137 \\
650 \\
936 \\
184\end{array}$ & $\begin{array}{r}98 \\
18 \\
0 \\
0 \\
0\end{array}$ & $\begin{array}{r}53 \\
2 \\
1 \\
0 \\
0\end{array}$ & $\begin{array}{r}337 \\
1459 \\
70 \\
132 \\
10\end{array}$ & $\begin{array}{r}20 \\
4 \\
0 \\
0 \\
0\end{array}$ & $\begin{array}{r}75 \\
385 \\
376 \\
172 \\
46\end{array}$ & $\begin{array}{r}1493 \\
2328 \\
1112 \\
1258 \\
252\end{array}$ \\
\hline $\begin{array}{l}\text { T1 } \\
23 \text { Mar 99, 06:00 h }\end{array}$ & $\begin{array}{c}0-25 \\
25-100\end{array}$ & $\begin{array}{r}311 \\
1\end{array}$ & $\begin{array}{r}15 \\
3\end{array}$ & $\begin{array}{r}755 \\
6\end{array}$ & $\begin{array}{r}65 \\
135\end{array}$ & $\begin{array}{l}0 \\
0\end{array}$ & $\begin{array}{r}26 \\
1\end{array}$ & $\begin{array}{r}533 \\
29\end{array}$ & $\begin{array}{l}0 \\
0\end{array}$ & $\begin{array}{r}323 \\
70\end{array}$ & $\begin{array}{r}1717 \\
244\end{array}$ \\
\hline $\begin{array}{l}\text { T2:1 } \\
23 \text { Mar 99, 09:00 h }\end{array}$ & $\begin{array}{c}0-25 \\
25-100\end{array}$ & $\begin{array}{r}188 \\
3\end{array}$ & $\begin{array}{r}10 \\
2\end{array}$ & $\begin{array}{r}615 \\
3\end{array}$ & $\begin{array}{l}213 \\
225\end{array}$ & $\begin{array}{r}34 \\
0\end{array}$ & $\begin{array}{r}74 \\
2\end{array}$ & $\begin{array}{r}1128 \\
94\end{array}$ & $\begin{array}{l}0 \\
0\end{array}$ & $\begin{array}{l}508 \\
103\end{array}$ & $\begin{array}{r}2582 \\
429\end{array}$ \\
\hline $\begin{array}{l}\text { T3 } \\
23 \text { Mar 99, 13:00 h }\end{array}$ & $\begin{array}{c}0-25 \\
25-100\end{array}$ & $\begin{array}{r}134 \\
0\end{array}$ & $\begin{array}{r}56 \\
0\end{array}$ & $\begin{array}{r}222 \\
7\end{array}$ & $\begin{array}{l}340 \\
479\end{array}$ & $\begin{array}{l}6 \\
0\end{array}$ & $\begin{array}{l}0 \\
0\end{array}$ & $\begin{array}{r}730 \\
99\end{array}$ & $\begin{array}{l}3 \\
0\end{array}$ & $\begin{array}{l}499 \\
116\end{array}$ & $\begin{array}{r}1856 \\
701\end{array}$ \\
\hline $\begin{array}{l}\text { T4:1 } \\
23 \text { Mar 99, 15:00 h }\end{array}$ & $\begin{array}{c}0-25 \\
25-100\end{array}$ & $\begin{array}{r}126 \\
0\end{array}$ & $\begin{array}{r}74 \\
3\end{array}$ & $\begin{array}{r}268 \\
3\end{array}$ & $\begin{array}{l}463 \\
230\end{array}$ & $\begin{array}{l}0 \\
0\end{array}$ & $\begin{array}{r}20 \\
0\end{array}$ & $\begin{array}{r}505 \\
64\end{array}$ & $\begin{array}{l}0 \\
0\end{array}$ & $\begin{array}{r}647 \\
69\end{array}$ & $\begin{array}{r}1977 \\
369\end{array}$ \\
\hline $\begin{array}{l}\text { H:1 } \\
25 \text { Mar 99, 24:00 h }\end{array}$ & $\begin{array}{c}0-10 \\
10-25 \\
25-40 \\
40-60 \\
60-100\end{array}$ & $\begin{array}{l}3 \\
0 \\
4 \\
4 \\
1\end{array}$ & $\begin{array}{r}37 \\
93 \\
42 \\
18 \\
9\end{array}$ & $\begin{array}{r}616 \\
132 \\
48 \\
12 \\
12\end{array}$ & $\begin{array}{r}0 \\
271 \\
383 \\
262 \\
123\end{array}$ & $\begin{array}{r}147 \\
0 \\
2 \\
1 \\
2\end{array}$ & $\begin{array}{r}80 \\
4 \\
0 \\
0 \\
0\end{array}$ & $\begin{array}{r}516 \\
683 \\
197 \\
83 \\
56\end{array}$ & $\begin{array}{r}10 \\
0 \\
0 \\
0 \\
0\end{array}$ & $\begin{array}{r}373 \\
2040 \\
191 \\
167 \\
42\end{array}$ & $\begin{array}{r}1779 \\
3223 \\
863 \\
543 \\
244\end{array}$ \\
\hline $\begin{array}{l}\mathrm{H}: 2 \\
26 \text { Mar 99, 12:00 h }\end{array}$ & $\begin{array}{l}0-10 \\
10-25 \\
25-40 \\
40-60 \\
60-100\end{array}$ & $\begin{array}{l}0 \\
0 \\
0 \\
5 \\
0\end{array}$ & $\begin{array}{r}12 \\
18 \\
7 \\
0 \\
1\end{array}$ & $\begin{array}{r}1789 \\
11 \\
6 \\
19 \\
5\end{array}$ & $\begin{array}{r}0 \\
562 \\
338 \\
426 \\
75\end{array}$ & $\begin{array}{r}157 \\
0 \\
0 \\
2 \\
0\end{array}$ & $\begin{array}{r}84 \\
0 \\
0 \\
0 \\
0\end{array}$ & $\begin{array}{r}436 \\
218 \\
77 \\
45 \\
16\end{array}$ & $\begin{array}{r}23 \\
0 \\
0 \\
0 \\
0\end{array}$ & $\begin{array}{r}105 \\
871 \\
251 \\
120 \\
21\end{array}$ & $\begin{array}{r}2606 \\
1680 \\
679 \\
612 \\
118\end{array}$ \\
\hline $\begin{array}{l}\text { (B) } \\
\text { Station }\end{array}$ & Depth & $\begin{array}{r}\text { Cal. } \\
(1080)\end{array}$ & $\begin{array}{l}\text { Par. } \\
(760)\end{array}$ & $\begin{array}{l}\text { Pseu. } \\
(780)\end{array}$ & $\begin{array}{l}\text { Mic. } \\
(400)\end{array}$ & $\begin{array}{l}\text { Tem. } \\
(900)\end{array}$ & $\begin{array}{l}\text { Ac. } \\
(720)\end{array}$ & $\begin{array}{l}\text { Oith. } \\
(370)\end{array}$ & $\begin{array}{l}\text { Cent. } \\
(840)\end{array}$ & $\begin{array}{l}\text { Micr. } \\
(420)\end{array}$ & Total \\
\hline $\begin{array}{l}\mathrm{K} \\
27 \text { Aug } 00,02: 30 \mathrm{~h}\end{array}$ & $\begin{array}{l}0-10 \\
10-25 \\
25-40 \\
40-60 \\
60-100\end{array}$ & $\begin{array}{r}330 \\
65 \\
12 \\
41 \\
48\end{array}$ & $\begin{array}{r}6080 \\
454 \\
16 \\
3 \\
13\end{array}$ & $\begin{array}{r}2780 \\
1670 \\
35 \\
203 \\
98\end{array}$ & $\begin{array}{r}0 \\
0 \\
0 \\
105 \\
492\end{array}$ & $\begin{array}{r}1178 \\
74 \\
18 \\
14 \\
6\end{array}$ & $\begin{array}{r}942 \\
445 \\
21 \\
85 \\
10\end{array}$ & $\begin{array}{r}5936 \\
2688 \\
129 \\
568 \\
353\end{array}$ & $\begin{array}{r}5983 \\
130 \\
2 \\
0 \\
8\end{array}$ & $\begin{array}{r}236 \\
1261 \\
693 \\
6038 \\
4072\end{array}$ & $\begin{array}{r}23226 \\
6721 \\
915 \\
7016 \\
505\end{array}$ \\
\hline $\begin{array}{l}\text { T2:1 } \\
28 \text { Aug } 00,16: 15 \text { h }\end{array}$ & $\begin{array}{c}0-10 \\
10-25 \\
25-40 \\
40-60 \\
60-100\end{array}$ & $\begin{array}{r}129 \\
55 \\
135 \\
16 \\
27\end{array}$ & $\begin{array}{r}1330 \\
94 \\
25 \\
5 \\
246\end{array}$ & $\begin{array}{r}427 \\
203 \\
80 \\
16 \\
46\end{array}$ & $\begin{array}{r}20 \\
0 \\
237 \\
336 \\
500\end{array}$ & $\begin{array}{r}60 \\
313 \\
26 \\
0 \\
22\end{array}$ & $\begin{array}{r}556 \\
86 \\
0 \\
0 \\
16\end{array}$ & $\begin{array}{r}4091 \\
9549 \\
4828 \\
570 \\
737\end{array}$ & $\begin{array}{r}566 \\
31 \\
0 \\
4 \\
72\end{array}$ & $\begin{array}{r}5322 \\
11637 \\
1342 \\
131 \\
2481\end{array}$ & $\begin{array}{r}13930 \\
20712 \\
4429 \\
869 \\
357\end{array}$ \\
\hline $\begin{array}{l}\text { T2:2 } \\
29 \text { Aug } 00,14: 00 \mathrm{~h}\end{array}$ & $\begin{array}{c}0-10 \\
10-25 \\
25-40 \\
40-60 \\
60-100\end{array}$ & $\begin{array}{r}41 \\
5 \\
5 \\
7 \\
5\end{array}$ & $\begin{array}{r}3177 \\
145 \\
31 \\
4 \\
12\end{array}$ & $\begin{array}{r}462 \\
209 \\
56 \\
5 \\
2\end{array}$ & $\begin{array}{r}27 \\
32 \\
408 \\
102 \\
46\end{array}$ & $\begin{array}{r}54 \\
118 \\
10 \\
3 \\
1\end{array}$ & $\begin{array}{r}353 \\
209 \\
194 \\
1 \\
5\end{array}$ & $\begin{array}{r}5499 \\
6272 \\
2485 \\
192 \\
94\end{array}$ & $\begin{array}{r}1208 \\
27 \\
0 \\
1 \\
3\end{array}$ & $\begin{array}{r}3150 \\
13701 \\
1245 \\
561 \\
195\end{array}$ & $\begin{array}{r}12371 \\
21913 \\
6540 \\
1063 \\
4120\end{array}$ \\
\hline $\begin{array}{l}\text { T3 } \\
1 \text { Sep 00, 16:45 h }\end{array}$ & $\begin{array}{c}0-10 \\
10-25 \\
25-40 \\
40-60 \\
60-100\end{array}$ & $\begin{array}{r}16 \\
13 \\
19 \\
7 \\
6\end{array}$ & $\begin{array}{r}479 \\
41 \\
24 \\
1 \\
2\end{array}$ & $\begin{array}{r}210 \\
70 \\
35 \\
1 \\
2\end{array}$ & $\begin{array}{r}0 \\
3 \\
418 \\
221 \\
172\end{array}$ & $\begin{array}{r}47 \\
8 \\
0 \\
0 \\
1\end{array}$ & $\begin{array}{r}51 \\
59 \\
19 \\
1 \\
1\end{array}$ & $\begin{array}{r}3893 \\
2267 \\
1139 \\
417 \\
2\end{array}$ & $\begin{array}{r}370 \\
52 \\
38 \\
1 \\
2\end{array}$ & $\begin{array}{r}3492 \\
4591 \\
2561 \\
190 \\
103\end{array}$ & $\begin{array}{r}8543 \\
7091 \\
4235 \\
832 \\
283\end{array}$ \\
\hline $\begin{array}{l}\text { T4 } \\
31 \text { Aug 00, 9:30 h }\end{array}$ & $\begin{array}{c}0-10 \\
10-25 \\
25-40 \\
40-60 \\
60-100\end{array}$ & $\begin{array}{r}90 \\
41 \\
19 \\
3 \\
0\end{array}$ & $\begin{array}{r}270 \\
9 \\
2 \\
19 \\
0\end{array}$ & $\begin{array}{r}316 \\
90 \\
69 \\
36 \\
0\end{array}$ & $\begin{array}{r}0 \\
0 \\
57 \\
763 \\
251\end{array}$ & $\begin{array}{r}301 \\
59 \\
2 \\
5 \\
0\end{array}$ & $\begin{array}{r}301 \\
18 \\
9 \\
8 \\
0\end{array}$ & $\begin{array}{r}6530 \\
3066 \\
425 \\
380 \\
0\end{array}$ & $\begin{array}{r}737 \\
9 \\
9 \\
9 \\
0\end{array}$ & $\begin{array}{r}14685 \\
4160 \\
2590 \\
1364 \\
57\end{array}$ & $\begin{array}{r}23142 \\
7411 \\
3165 \\
2584 \\
308\end{array}$ \\
\hline
\end{tabular}


sured and dried at $60^{\circ} \mathrm{C}$ for $24 \mathrm{~h}$. The dry weight was then measured with a Mettler Toledo MT5 and carbon content of females was finally measured with a CHNSElemental Analyser (EA 1110 CHNS CE instruments). The carbon signal was calibrated against a standard curve of methionine. A length-weight regression measurement was only conducted in spring.

Statistical analyses. ANOVA with a significance level of $5 \%$ was used to test the difference between means. To compare gut evacuation rates between day and night, ANCOVA was used with time as covariate. The mean values are indicated as \pm SD in the text and tables. Regression analyses were conducted using a significance level of $5 \%$. All statistical tests were conducted using Statistical Package of Social Science (SPSS 12.0.1) for windows.

\section{RESULTS}

\section{Potential food}

Copepods dominated the zooplankton community during both seasons; detailed reports are presented in Maar et al. (2002, 2004). In the spring, abundance of small copepods (excluding nauplii) ranged from 2940 (Stn K:1) to 1490 (Stn K:2) ind. $\mathrm{m}^{-3}$ in the 0-10 m layer and from 3220 (Stn H:1) to 1680 ind. $\mathrm{m}^{-3}$ (Stn H:2) in the 10-25 m layer (Table 2A). The highest abundance was recorded for Pseudocalanus sp., Oithona similis and Microsetella norvegica. The total prey abundance for the transect stations ranged from 2580 (Stn T2:1) to 1717 (Stn T1) ind. $\mathrm{m}^{-3}$ in the $0-25 \mathrm{~m}$ layer and from 701 (Stn T3) to 244 ind. $\mathrm{m}^{-3}$ (Stn T1) in the $25-100 \mathrm{~m}$ layer (Table 2A). Prey abundance showed no differences between day and night. The prey abundance for most species was 10 times higher in the autumn. The abundance of small copepods ranged from 23200 (Stn $\mathrm{K})$ to 8500 (Stn T3) ind. $\mathrm{m}^{-3}$ in the $0-10 \mathrm{~m}$ layer and from 21900 (Stn T2:2) to 6700 ind. $\mathrm{m}^{-3}$ (Stn K) in the 10-25 m layer (Table 2B). Highest abundances were recorded for Paracalanus parvus, Oithona similis and Microsetella norvegica. No differences between day and night were found.

\section{Abundance of Pareuchaeta norvegica}

The abundance of Pareuchaeta norvegica ranged from 0 to 17 ind. $\mathrm{m}^{-3}$ in spring with peak abundance recorded in the 25-100 m layer at night at Stn T2 (Fig. 2). No clear vertical migration was observed. In autumn; abundances ranged from 0 to 40 ind. $\mathrm{m}^{-3}$ with highest records in the surface layer at night at Stn T2 (Fig. 2). The abundance at the coastal station (Stn K)

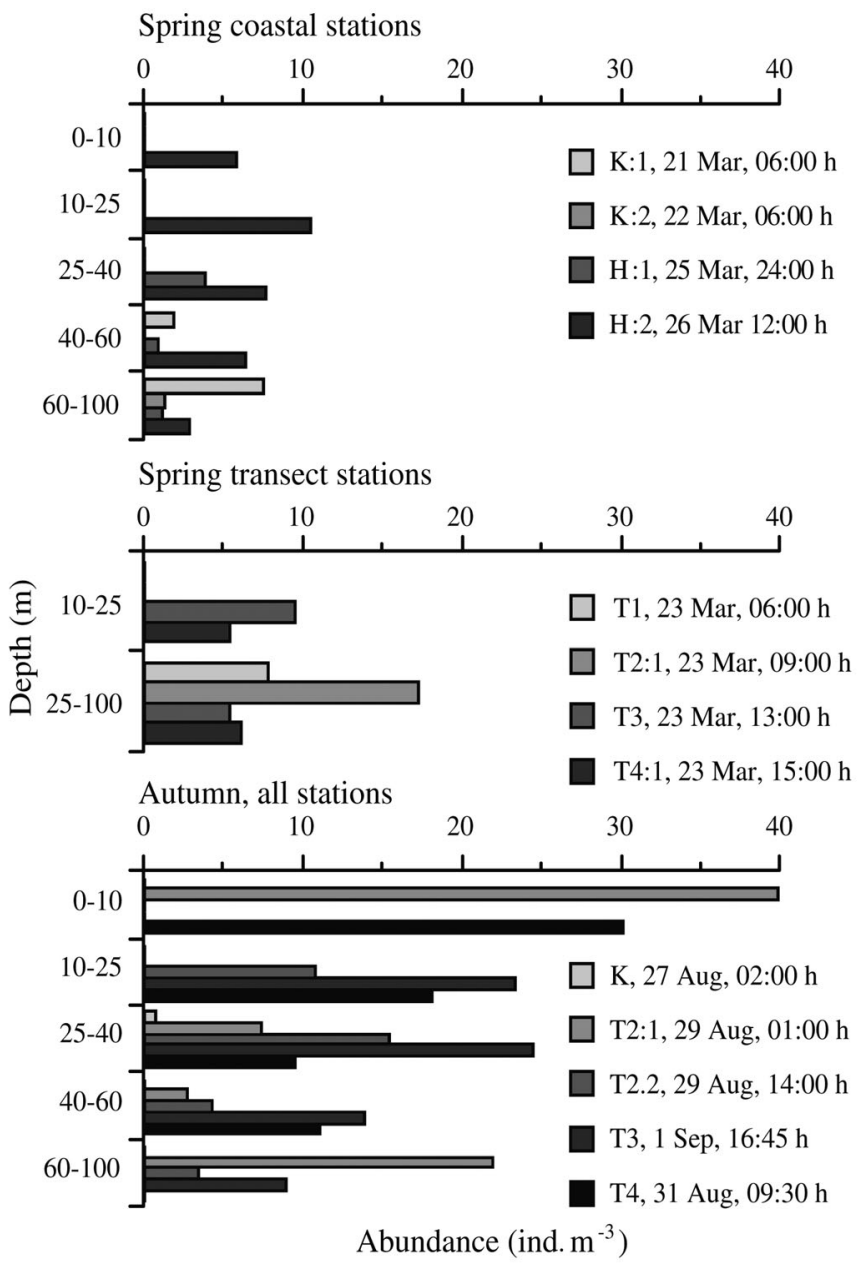

Fig. 2. Pareuchaeta norvegica. Vertical distributions (ind. $\mathrm{m}^{-3}$ ) of all stages in the Skagerrak in spring 1999 and autumn 2000

was very low $\left(<1\right.$ ind. $\left.\mathrm{m}^{-3}\right)$. P. norvegica showed a strong vertical migration at the deepest transect station (Stn T2).

Females were significantly more abundant than males during both seasons (Table 3 ). The proportion of males ranged from 0.18 to 0.38 in spring and from 0.07 to 0.15 in autumn. The number of spermatophores per female was significantly higher in spring, ranging from 0.71 to 0.90 while the number ranged from 0.37 to 0.48 in autumn.

\section{Gut content}

All statistical results are shown in Table 4 . The gut content of copepodites (stages CIV-CV) ranged from 4.5 to 11.2 pellets ind..$^{-1}$ in spring and from 3.8 to 6.8 pellets ind. ${ }^{-1}$ in autumn with no significant differences between seasons (Fig. 3). Gut content of females was significantly lower than that of copepodites, irrespec- 
Table 3. Pareuchaeta norvegica. Proportions of males in the adult population, mean number of spermatophores per female and number of females carrying different numbers of spermatophores in spring and autumn

\begin{tabular}{|c|c|c|c|c|c|c|c|}
\hline \multirow[t]{2}{*}{ Station } & \multirow[t]{2}{*}{$\begin{array}{c}\text { Proportion } \\
\text { of } \\
\text { males }\end{array}$} & \multirow[t]{2}{*}{$\begin{array}{l}\text { Spermatophore } \\
\text { no. female }\end{array}$} & \multicolumn{5}{|c|}{$\begin{array}{c}\text { No. of females } \\
\text { carrying different } \\
\text { no. of spermataphores }\end{array}$} \\
\hline & & & 0 & 1 & 2 & 3 & 4 \\
\hline \multicolumn{8}{|l|}{ Spring } \\
\hline $\mathrm{K}: 2$ & 0.38 & 0.90 & 6 & 12 & 2 & 1 & 0 \\
\hline T1 & 0.28 & 0.86 & 13 & 31 & 4 & 1 & 0 \\
\hline T2:1 & 0.22 & 0.76 & 35 & 70 & 6 & 1 & 0 \\
\hline T3 & 0.18 & 0.71 & 23 & 53 & 2 & 0 & 0 \\
\hline $\mathrm{T} 4: 1$ & 0.33 & 0.88 & 6 & 25 & 5 & 1 & 1 \\
\hline $\mathrm{H}: 1$ & 0.19 & 0.75 & 16 & 33 & 3 & 0 & 0 \\
\hline \multicolumn{8}{|c|}{ Autumn } \\
\hline T2:1 & 0.11 & 0.46 & 51 & 39 & 2 & 0 & 0 \\
\hline T2:2 & 0.088 & 0.42 & 33 & 16 & 3 & 0 & 0 \\
\hline T3 & 0.067 & 0.37 & 63 & 28 & 4 & 0 & 0 \\
\hline T4 & 0.15 & 0.48 & 47 & 34 & 3 & 0 & 0 \\
\hline
\end{tabular}

tive of season, ranging from 1.4 to 6.4 pellets ind. ${ }^{-1}$ in spring to 2.7 to 4.4 pellets ind. ${ }^{-1}$ in autumn (Fig. 3). Although diurnal sampling was not carried out at all stations, gut content was significantly higher at night for both copepodites and adults. Most adult females of Pareuchaeta norvegica contained 2 to 4 prey (pellets) while up to 6 to 8 prey items were relatively common in juveniles (Fig. 4). Very few females were empty (6\%) and all copepodites contained prey.

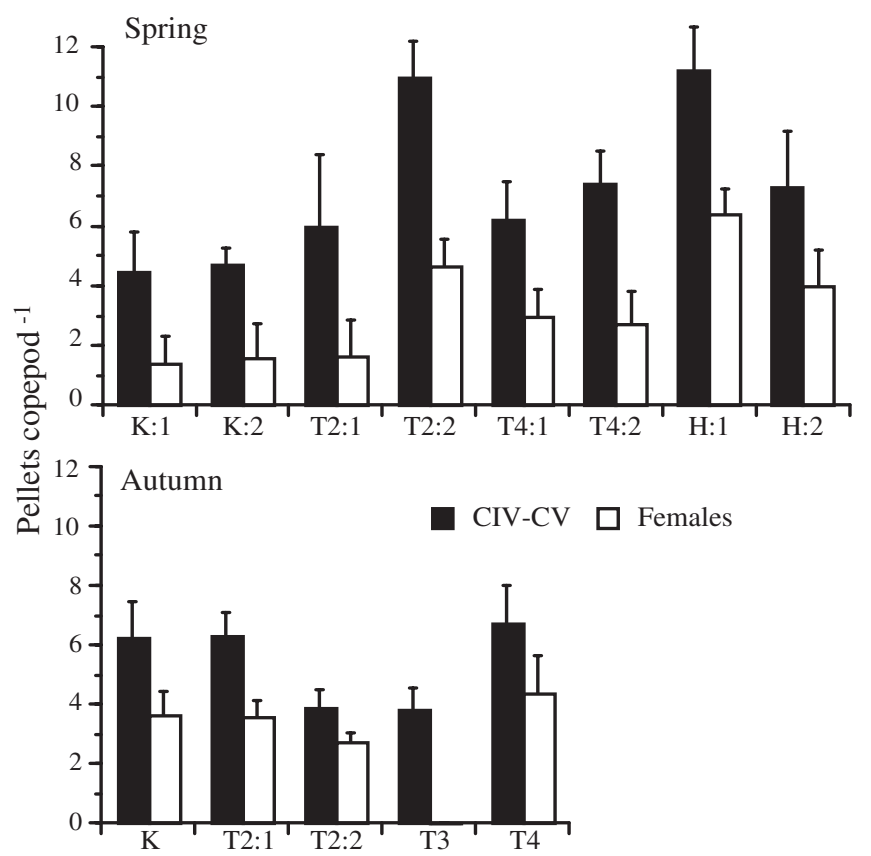

Fig. 3. Pareuchaeta norvegica. Gut content (pellets copepod $^{-1}$ ) of CIV-CV copepodites and females collected at $0-50 \mathrm{~m}$ depth
Table 4. Pareuchaeta norvegica. Statistical results, ANOVA, testing the difference between means with a significance level of $0.05 .{ }^{* * *} \mathrm{p}<0.001,{ }^{* *} \mathrm{p}<0.01,{ }^{*} \mathrm{p}<0.05, \mathrm{~ns}=$ not significant. J: juveniles (CIV-CV); F: females; A: autumn; S: spring; D: day; N: night; NP: number of pellets in gut (gut content); FR: feeding rate; $P L$ : prosome length, $S E P$ : specific egg production; No. F with egg sacs: number of females with egg sacs; No. sperm $\mathrm{F}^{-1}$ : number of spermatophores per female; $\mathrm{M}: \mathrm{F}$ : the proportion of males in the adult population; $\mathrm{C}$ : carbon weight

\begin{tabular}{|lcc|}
\hline & $F$ & Significance \\
\hline Pellet experiments & & \\
NP J, S vs A & 2.25 & $\mathrm{~ns}$ \\
NP F, S vs A & 0.20 & $\mathrm{~ns}$ \\
NP S, J vs F & 4.45 & ${ }^{* * *}$ \\
NP A, J vs F & 24.8 & ${ }^{* * *}$ \\
NP J S, N vs D & 9.76 & ${ }^{* *}$ \\
NP J A, N vs D & 11.6 & ${ }^{* *}$ \\
NP F S, N vs D & 12.9 & ${ }^{* *}$ \\
NPF A, N vs D & 9.13 & ${ }^{* *}$ \\
$F R$ F, S vs A & 19.1 & ${ }^{* *}$ \\
$F R$ J, S vs A & 6.82 & ${ }^{* *}$ \\
$F R$ S, J vs F & 11.1 & ${ }^{* *}$ \\
FR A, J vs F & 5.23 & $n s$ \\
Egg production experiments & & \\
$P L$ F, S vs A & 75.8 & ${ }^{* * *}$ \\
SEP, S vs A & 0.20 & $\mathrm{~ns}$ \\
No. F with egg sacs, S vs A & 75.8 & ${ }^{* * *}$ \\
No. sperm. F ${ }^{-1}$, S vs A & 70.7 & ${ }^{* * *}$ \\
M:F, S vs A & 13.5 & ${ }^{* *}$ \\
Egg size, S vs A & 1.24 & $\mathrm{~ns}$ \\
C F, S vs A & 73.9 & ${ }^{* * *}$ \\
\hline
\end{tabular}

The females were significantly larger in the spring $(5.5 \pm 0.2 \mathrm{~mm})$ compared to autumn $(5.2 \pm 0.2 \mathrm{~mm})$ (Table 5). Prosome lengths for stages CV and CIV were $4.1 \pm 0.3$ and $2.7 \pm 0.2 \mathrm{~mm}$, respectively, in spring, and $4.0 \pm 0.2$ and $2.5 \pm 0.3 \mathrm{~mm}$ in autumn. Pellet size followed animal size ranging from $500 \times 136 \mu \mathrm{m}$ for the larger females to $400 \times 95 \mu \mathrm{m}$ for copepodites (CIV-CV). The investigation of a small number of pellets $(n=30)$ showed remains of copepods, in the form of mandibles and other parts of appendages, in all pellets. No other prey items were found. The mortality of Pareuchaeta norvegica in the faecal pellet experiments was low $(0.8 \%, \mathrm{n}=186$ in spring; $1.1 \%, \mathrm{n}=130$ in autumn).

\section{Gut evacuation}

The gut evacuation experiments were run for $48 \mathrm{~h}$ in both seasons. Pareuchaeta norvegica produced pellets for $37 \mathrm{~h}$ in spring and $21 \mathrm{~h}$ in autumn (Fig. 5). The decline in gut content was exponential over time with no significant difference between day and night (ANCOVA, Ln (natural log) pellets as dependent, time as covariate; interaction term not significant). The 
common slope of the 2 regressions in the spring was -0.047 ; that is, $4.7 \%$ of the gut content was expelled as pellets each hour at $5^{\circ} \mathrm{C}$. As in spring, the 2 slopes in autumn were not different and the common slope of the 2 regressions in the autumn was -0.080 at $15^{\circ} \mathrm{C}$. The mortality of $P$. norvegica in the experiments was low in both spring $(3 \%, \mathrm{n}=150)$ and autumn $(2 \%$, $\mathrm{n}=120$ ). Statistical results are shown in Table 4 .

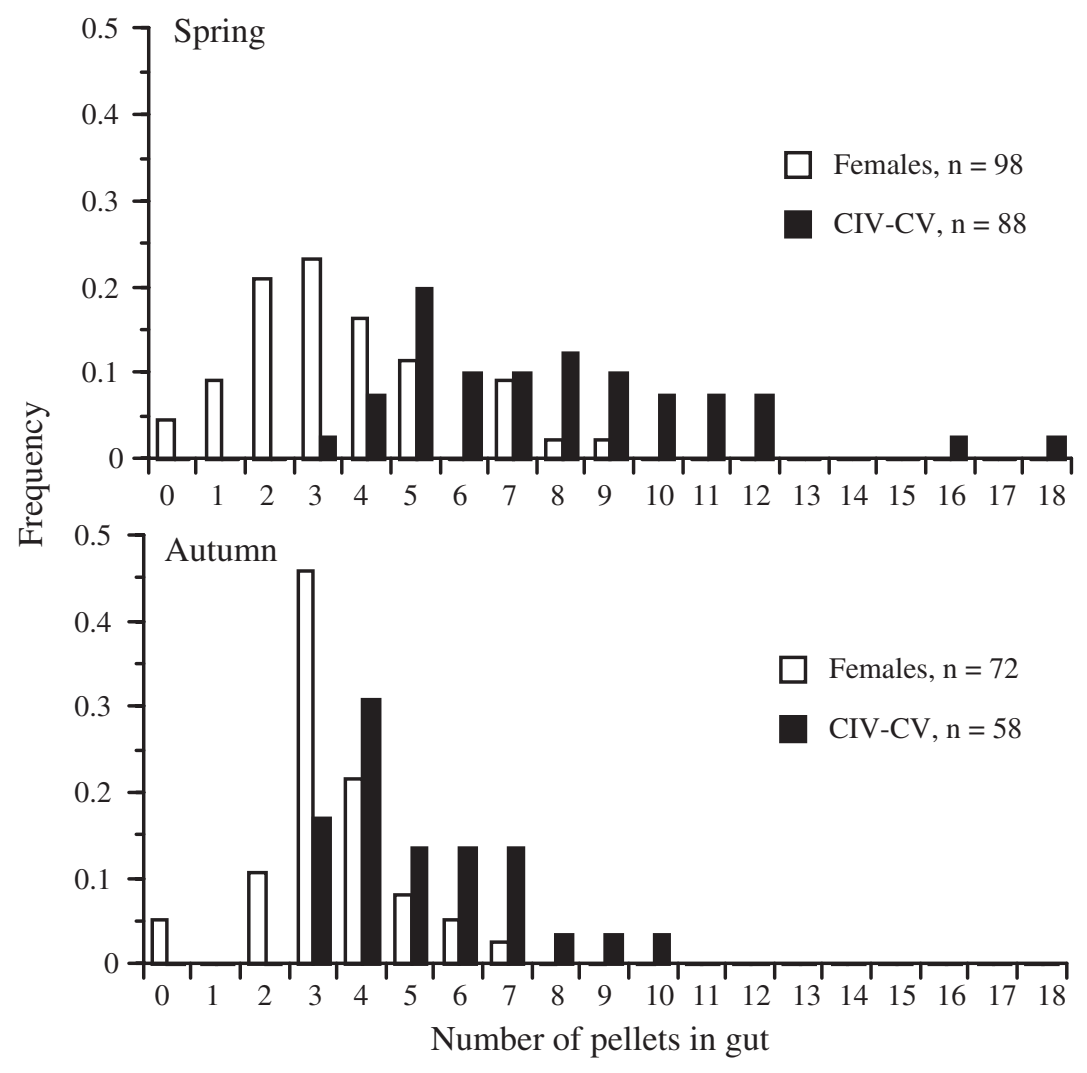

Fig. 4. Pareuchaeta norvegica. Frequency distributions of the number of pellets in the guts of CIV-CV copepodites and females. All stations pooled; $\mathrm{n}=$ number of individuals investigated

\section{Egg hatching}

The average number of eggs carried in each egg mass ranged from 27.8 to 29.4 in spring and from 22.4 to 25.2 in autumn (Table 5), with a significantly larger brood size in spring. Females with attached spermatophores and egg sacs were found in both seasons. In spring, 25 to $44 \%$ of the females carried egg sacs while significantly fewer were pregnant in the autumn (11 to $15 \%$, Table 5). Furthermore, the number of spermatophores per female was significantly higher in spring. Females with more than 2 spermatophores were only found in spring (Table 3), and all spermatophores found were attached to the genital segment. There were significant relationships between prosome length $(P L, \mathrm{~mm})$ and both the number of eggs $(E)$ and the volume of the egg clutch $(V, \mu l)$ :

$$
\begin{array}{ll}
E=20.7 P L-84.6 & \mathrm{R}^{2}=0.72 \\
V=1.04 P L-4.50 & \mathrm{R}^{2}=0.66
\end{array}
$$

Egg diameter was the same in both seasons and had a value of $425 \pm 13 \mu \mathrm{m}$ $(\mathrm{n}=180)$.

Table 5. Pareuchaeta norvegica. Female prosome length $(\mathrm{mm})$, carbon weight ( $\mu \mathrm{g} \mathrm{C})$, percentage of egg carrying females $(\%)$, brood size (eggs brood $\left.^{-1}\right)$, the egg to female ratio, egg diameter $(\mu \mathrm{m})$ and weight-specific egg production $\left(S E P, \% \mathrm{~d}^{-1}\right)$ at the stations in spring and autumn. SEP calculated assuming an egg carbon content of $12.6 \mu \mathrm{g} \mathrm{C}$ (Nemoto et al. 1976) and using the

\begin{tabular}{|c|c|c|c|c|c|c|c|}
\hline Station & $\begin{array}{l}\text { Prosome length } \\
\text { mm }( \pm \text { SD })\end{array}$ & $\begin{array}{c}\text { Carbon weight } \\
\mu \mathrm{g}( \pm \mathrm{SD})\end{array}$ & $\begin{array}{l}\text { Percentage } \\
\text { bearing eggs }\end{array}$ & $\begin{array}{l}\text { Brood size } \\
\quad( \pm \mathrm{SD})\end{array}$ & $\begin{array}{l}\text { Egg: } \\
\text { female }\end{array}$ & $\begin{array}{l}\text { Egg diameter } \\
\qquad( \pm \mathrm{SD})\end{array}$ & $\begin{array}{c}S E P \\
\% \mathrm{~d}^{-1}( \pm \mathrm{SD})\end{array}$ \\
\hline \multicolumn{8}{|l|}{ Spring } \\
\hline $\mathrm{K}: 2$ & $5.60(0.16)$ & 1006 (19) & 43 & $29.4(5.6)$ & 12.6 & 434 (15) & $0.50(0.11)$ \\
\hline $\mathrm{T} 2: 1$ & $5.53(0.15)$ & 914 (17) & 25 & $28.4 \quad(5.2)$ & 7.10 & 428 (11) & $0.31(0.06)$ \\
\hline $\mathrm{T} 4: 1$ & $5.48(0.15)$ & 857 (16) & 44 & $28.5(4.6)$ & 12.47 & $423(14)$ & $0.73(0.15)$ \\
\hline $\mathrm{H}: 1$ & $5.44(0.15)$ & 814 (15) & 38 & $27.8(5.1)$ & 10.43 & $423(10)$ & $0.58(0.12)$ \\
\hline Mean & $5.51(0.17)$ & & & $28.6(5.2)$ & 10.65 & 427 (13) & $0.54 \quad(0.19)$ \\
\hline \multicolumn{8}{|l|}{ Autumn } \\
\hline $\mathrm{T} 2: 1$ & $5.26(0.20)$ & $652(16)$ & 14 & $24.3(5.9)$ & 3.30 & 433 (15) & $0.51(0.16)$ \\
\hline $\mathrm{T} 2: 2$ & $5.23(0.15)$ & $623(12)$ & 14 & $24.4 \quad(5.2)$ & 3.32 & 421 (16) & $0.47(0.08)$ \\
\hline T3 & $5.19(0.16)$ & 590 (13) & 15 & $25.2(4.7)$ & 3.88 & 421 (15) & $0.66(0.14)$ \\
\hline $\mathrm{T} 4$ & $5.13(0.15)$ & 540 (11) & 11 & $22.4 \quad(4.4)$ & 2.35 & 417 (12) & $0.42(0.08)$ \\
\hline Mean & $5.20(0.18)$ & & & $24.2(5.3)$ & 3.2 & 422 (16) & $0.51(0.14)$ \\
\hline
\end{tabular}
best-fit regression model in Table 6 

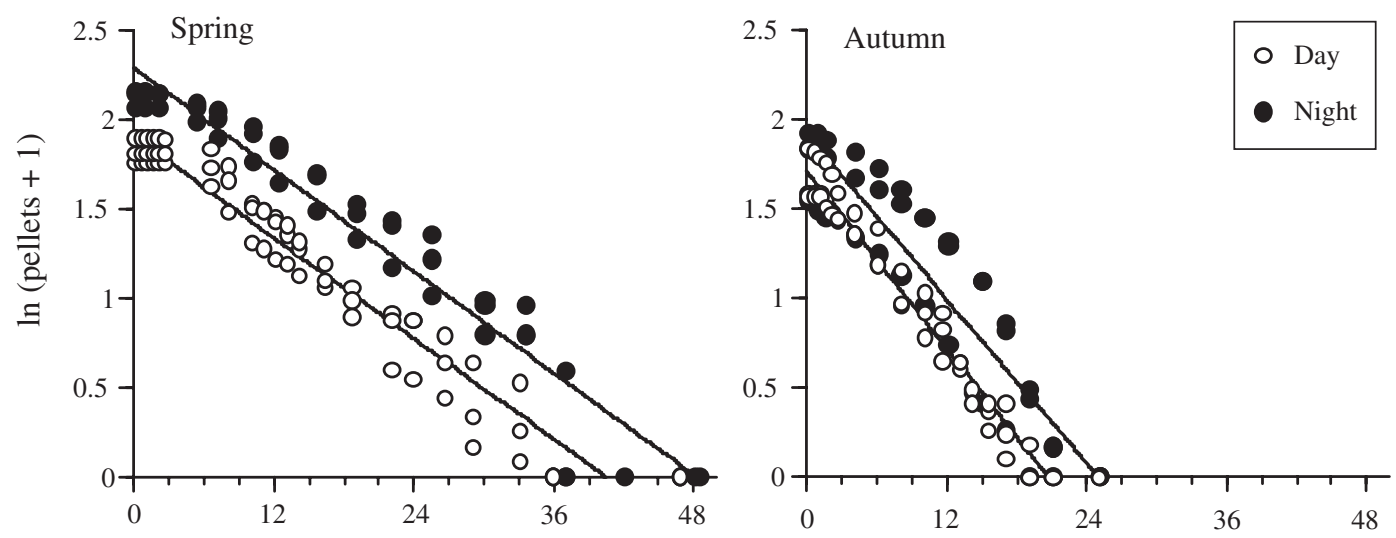

Time (h)

Fig. 5. Pareuchaeta norvegica. Gut evacuation during the day and at night in spring and autumn. Gut content is the number of pellets in the gut transformed to $\ln$ (pellets +1 ). Linear regressions where the slope equals gut evacuation rate $\left(\mathrm{h}^{-1}\right)$ are indicated. ANCOVA showed that slopes did not differ between day and night, and rates were $-0.047 \mathrm{~h}^{-1}$ in spring and $-0.080 \mathrm{~h}^{-1}$ in autumn

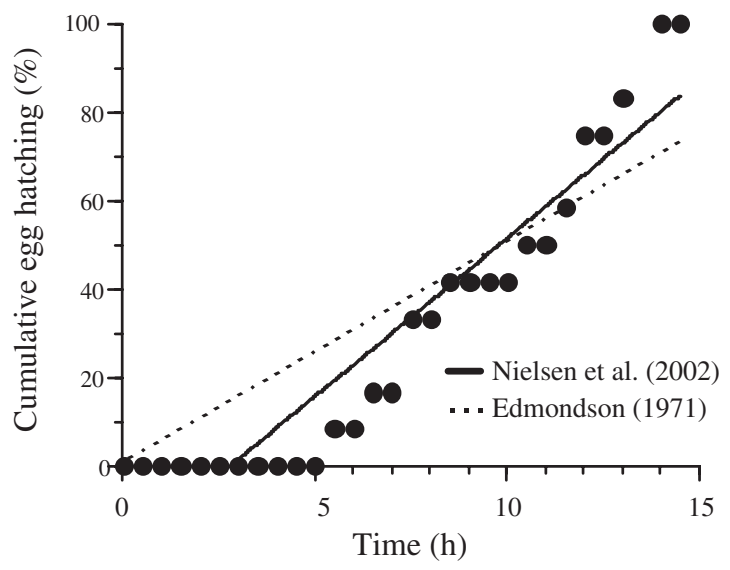

Fig. 6. Pareuchaeta norvegica. The 2 different ways by which linear regression was applied to estimate egg-hatching rates. Example from the egg-hatching experiment in autumn at Stn $\mathrm{T} 3\left(15^{\circ} \mathrm{C}\right)$. Hatching rates $\left(H R_{r} \% \mathrm{~d}^{-1}\right)$ are the slopes of the linear regression of cumulative hatching percentage vs time. Dotted line: method used originally by Edmondson (1971) where the regression line is forced through the origin $(H R=$ $5.1 \% \mathrm{~d}^{-1}, \mathrm{R}^{2}=0.77$ ). Solid line: modified method used by Nielsen et al. (2002) where the best fit for regression without a 0 -intercept is used $\left(H R=7.2 \% \mathrm{~d}^{-1}, \mathrm{R}^{2}=0.89\right)$

The hatching rate $\left(H R, \% \mathrm{~d}^{-1}\right)$ was estimated from the modified method used in Nielsen et al. (2002) where the best fit of the regression without the 0-intercept was used (Fig. 6). This modified method was used since the females with egg sacs in the hatching experiment may not represent the population, since egg sacs are easily detached during handling. Studies have shown that Oithona sp. with older egg sacs are more likely to drop their egg sacs during collection and handling (own observations). Average hatching rates were 3.4 and $7.3 \% \mathrm{~d}^{-1}$ in spring and autumn, respectively (Table 6). Weight-specific egg production ( $\mu \mathrm{g} \mathrm{C} \mu \mathrm{g} \mathrm{C}$ $\mathrm{d}^{-1}$ ) was remarkably similar over seasons, 0.51 to $0.54 \%$ body $\mathrm{C} \mathrm{d}^{-1}$ and showed no spatial pattern (Table 3). The mortality during the 2 wk incubation was $5 \%$ in spring $(n=40)$ and $6 \%$ in autumn $(n=44)$. Statistical results are shown in Table 4.

\section{Length-weight regressions}

There was a significant relationship between prosome length and carbon $(\mathrm{C}, \mathrm{mg})$ or dry weight (DW, mg) for females:

$$
\begin{aligned}
& \log \mathrm{C}=6.92 \log P L-5.18 \quad \mathrm{R}^{2}=0.74 \\
& \log \mathrm{DW}=5.77 \log P L-3.95 \mathrm{R}^{2}=0.84
\end{aligned}
$$

The carbon to body dry weight ratio for females was on average $41 \pm 4 \%$. The female carbon content was significantly higher in spring, $901 \pm 19 \mu \mathrm{g} \mathrm{C}(\mathrm{n}=46)$ than in autumn, $604 \pm 14 \mu \mathrm{g} \mathrm{C}(\mathrm{n}=46)$. For copepodites (CII-CV), the length-weight regressions were different than for females with significantly lower slopes (non-overlapping confidence intervals):

$$
\begin{array}{ll}
\log \mathrm{C}=3.01 \log P L-2.37 & \mathrm{R}^{2}=0.83 \\
\log \mathrm{DW}=2.99 \log P L-1.8 & \mathrm{R}^{2}=0.85
\end{array}
$$

The carbon to body dry weight ratio for juveniles was on average $32 \pm 4 \%$ which is significantly lower than for females $(\mathrm{p}<0.001)$.

\section{DISCUSSION}

\section{Gut content}

Gut contents, calculated from pellet production, were highest in juveniles, who produced more pellets 
than the females in both seasons. The gut contents in our study, and the higher values for juveniles, are within the range reported by Kaartvedt et al. (2002) and Skarra \& Kaartvedt (2003). The average pellet production rates for both females and juveniles were significantly higher at night in both seasons but the long gut evacuation time may obscure the differences between day and night. Increased gut content at night has been shown in the Norwegian fjords by Olsen et al. (2000), Kaartvedt et al. (2002) and Skarra \& Kaartvedt (2003). Increased feeding rates during night-time coupled to vertical migration might be a direct consequence of encounter with higher prey densities (Gauld 1953), but might also result from enhanced feeding activity (Mackas \& Bohrer 1976). Empty females were present in both seasons (Fig. 4), and the occurrence of specimens with empty guts may indicate that feeding in the natural environment is not continuous (Øresland 1990).

The female pellet length was in the same range as the pellet length in Skarra \& Kaartvedt (2003, $\sim 485 \mu \mathrm{m})$. Yen (1987) found slightly longer pellets from females $(\sim 547 \mu \mathrm{m})$ and CV copepodites $(\sim 441 \mu \mathrm{m})$, which is probably a result of larger females and copepodites, and a different diet (fish larvae) in her experiments. The total dominance of copepod remains in pellets from Pareuchaeta norvegica is in accordance with earlier studies on the diet of Euchaeta species (e.g. Båmstedt \& Holt 1978, Yen 1982b, 1985, Øresland 1991, Øresland \& Ward 1993).
To our knowledge, this is the first report on gut evacuations rates for Pareuchaeta norvegica feeding on small copepods. Yen (1987) found a considerably higher gut evacuation rate $\left(0.43 \mathrm{~h}^{-1}\right)$ for $P$. norvegica feeding on cod larvae at $7.5^{\circ} \mathrm{C}$. Digestion of larvae may, however, be much more rapid than that of crustaceans. Furthermore, ingestion of a very large prey $(\operatorname{cod}$ larvae $=3.7 \mathrm{~mm})$ may induce another mode of packaging the pellet. The turnover rate of stomach contents increased with temperature and consequently increased the feeding capacity. The relationship between temperature $(T)$ and gut evacuation rate $(R)$ may be described by the $Q_{10}$ equation:

$$
Q_{10}=\left(\frac{R_{1}}{R_{2}}\right)^{\frac{10}{\left(T_{1}-T_{2}\right)}}
$$

where $R_{1}$ and $R_{2}$ are gut evacuation rates at temperatures $T_{1}$ and $T_{2}$. The $\mathrm{Q}_{10}\left(5\right.$ to $15^{\circ} \mathrm{C}$ ) for gut evacuation was 1.7 .

\section{Egg hatching}

Since Pareuchaeta norvegica is a vertically migrating species, the temperature will change over the day for copepods in the field. The temperature chosen in the experiments was an average over 0 to $25 \mathrm{~m}$ and might be slightly too high in autumn. This might be a significant source of error in the calculation of egg hatching and gut evacuation rates. The hatching times in this study were $34 \mathrm{~d}$ in spring $\left(5^{\circ} \mathrm{C}\right)$ and $17 \mathrm{~d}$ in autumn $\left(15^{\circ} \mathrm{C}\right)$. Hopkins $(1977)$ found that the average time taken from egg laying to hatching was $18.7 \pm 1.2 \mathrm{~d}$ at $10^{\circ} \mathrm{C}$ for $P$. norvegica. For $P$. antarctica, the average time was $23.7 \mathrm{~d}$ at $2{ }^{\circ} \mathrm{C}$ (Alonzo et al. 2000). During our experiments, the hatching rates varied between 3.4 and $7.2 \% \mathrm{~d}^{-1}$ depending on the temperature (Table 6), which gives a $\mathrm{Q}_{10}$ of 2.15. Weight-specific egg production was the same in both seasons, $0.5 \% \mathrm{~d}^{-1}$. This reflects the higher egg hatching rate but a lower egg:female ratio in the autumn as compared to spring.

In the present study, no seasonal variation in egg size was recorded and no relation between egg size and female body weight was found. These results are in line with earlier studies (Nemoto et al. 1976, Hopkins 1977). Furthermore, the low number of eggs carried in each egg mass obtained in this study, compared to species that 
release their eggs in to the water column, is consistent with the fecundity of egg-carrying species (Kiørboe \& Sabatini 1995). The average daily production in both seasons was lower than the production reported by Hopkins (1977). Significant relationships between the number of eggs and prosome length, and between the volume of the egg clutch and prosome length as found in this study, have been reported earlier by Hopkins (1977); however, Nemoto et al. (1976) did not find any clear relationship between body size and the number of eggs.

The number of spermatophores per female and the proportion of males were highest in spring (Table 5). Clearly, a higher rate of fertilisation occurred in spring. Our data support the correlation between the mean number of spermatophores per female and the proportion of adult males shown earlier by Hopkins (1982). Hopkins also showed that adult males had 2 peak periods in Loch Etive, Scotland, the first in March and the second in early July, and that the peak of adult male abundance occurred concurrently with the peak of spermatophore attachment and the peak of number of females carrying egg sacs. Analyses of the frequency distribution of spermatophores on females show that, although females carrying several spermatophores can be found, multiple placements are rare. A maximum of $22 \%$ (Stn T4; spring) of the females with spermatophores carried more than one. These results are consistent with Hopkins (1982), where only $17.5 \%$ of the females with spermatophores carried more than one. Both results are in accordance with the fact that the majority of calanoid copepods only receive 1 spermatophore during the production of 1 brood of eggs (Mauchline 1998). Up to 4 spermatophores were found on a single female in our study. Multiple spermatophores have been reported in some calanoid copepod species, and have most commonly been reported in the Euchaetidae (Katona 1975, Ward \& Robins 1987, Mauchline 1994). Hopkins \& Machin (1977) found females carrying up to 6 spermatophores, all of which were attached to the genital segment, indicating that the placement of the spermatophore on a female is relatively precise.

\section{Feeding rates}

Feeding rates were measured indirectly by estimating pellet production. Since digestion times are temperature dependent, the colder surface water in spring resulted in significantly lower feeding rates for Pareuchaeta norvegica females and juveniles even though gut content was similar in both seasons. Feeding rates for females ranged from 1.4 to 5.2 prey d $^{-1}$ in spring and from 6.2 to 8.6 prey d $^{-1}$ in autumn (Fig. 7 ).
The feeding rates for juveniles in the spring were significantly higher than for females, ranging from 4.6 to 9.2 prey $^{-1}$. In the autumn, feeding rates for juveniles were slightly, but not significantly, higher than for females ranging from 7.6 to 13.2 prey $^{-1}$. The feeding rates for females in this study are in accordance with the experimental feeding rate in Olsen et al. (2000) of 3.6 prey female ${ }^{-1} \mathrm{~d}^{-1}$.

The average daily ration of an adult Pareuchaeta norvegica female can be estimated if we estimate ingestion from pellet production and assume 1 pellet $=1$ prey. Copepods dominated the zooplankton community in both seasons. The prey abundance in autumn, especially in the surface layer, was 10-fold higher than in early spring. There was also a difference in species composition between seasons; Pseudocalanus sp. was common in the spring while Paracalanus sp. dominated in the autumn. If we assume that the prey were Pseudocalanus CV copepodites in the spring and Paracalanus parvus $\mathrm{CV}$ copepodites in the autumn, the daily ration (carbon/carbon) for females was $2 \%$ in spring and $4 \%$ in autumn. This prey preference is supported by Yen (1985) who found that Pseudocalanus sp. was the preferred prey in a field study of the congener Euchaeta elongata. The daily rations are low compared with other carnivorous zooplankton (Alvarez \& Matthews 1975, Corner et al. 1976) but in accordance with earlier estimates for P. norvegica (Båmstedt \& Holt 1978).

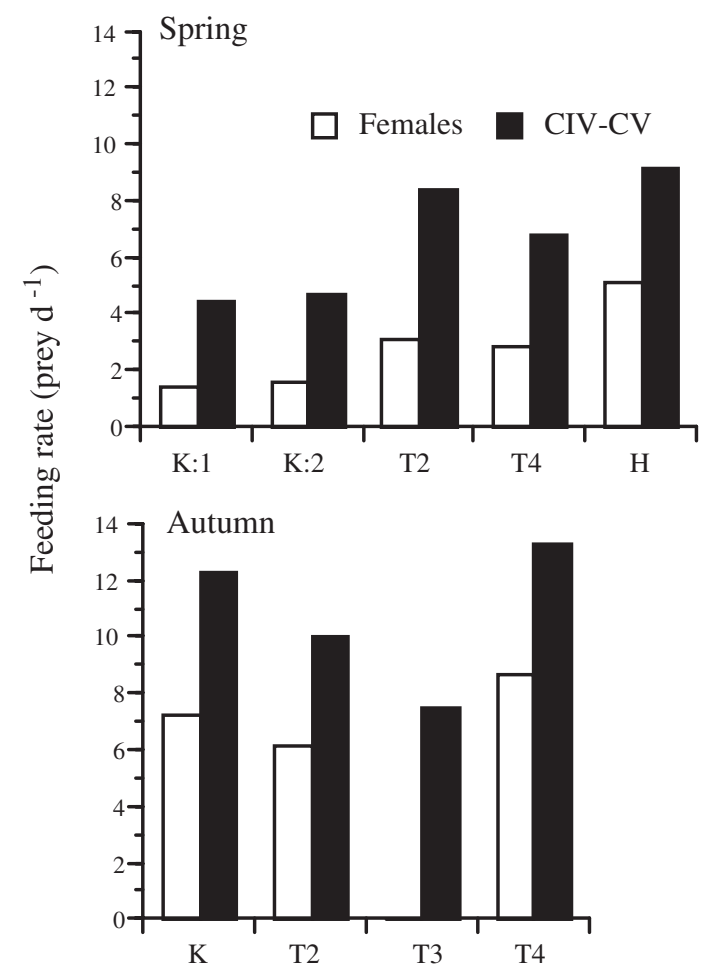

Fig. 7. Pareuchaeta norvegica. Feeding rates (prey $\mathrm{d}^{-1}$ ) in spring and autumn for females and CIV-CV copepodites 
Ingestion and daily ration for females can be calculated from the faecal pellet carbon content and absorption efficiency. The carbon content of pellets was calculated using the ratio $0.057 \mathrm{mg} \mathrm{C} \mathrm{mm}^{-3}$ reported by González et al. (1994). The average pellet volume in spring and autumn was $6.8 \times 10^{6}$ and $7.3 \times 10^{6} \mathrm{\mu m}^{3}$, respectively, which give carbon contents of 0.39 and $0.42 \mu \mathrm{g} C$ pellet $^{-1}$, respectively. An absorption efficiency of $92 \%$ (Båmstedt \& Holt 1978) gives an average ingestion of $16.3 \mu \mathrm{g} \mathrm{C} \mathrm{d}^{-1}$ in spring and $29.1 \mu \mathrm{g} \mathrm{C}$ $\mathrm{d}^{-1}$ in autumn. The daily ration for females calculated in this way was $1.8 \%$ in spring and $4.8 \%$ in autumn, very similar to the previous estimate. This supports the idea that small calanoid copepods of Paracalanus/ Pseudocalanus were the main prey of Pareuchaeta norvegica in the Skagerrak. Furthermore, the assumption of 1 prey = 1 pellet seems well founded for these crustacean prey.

Ingestion for females can also be calculated from weight-specific egg production assuming a gross growth efficiency of $33 \%$. This crude calculation shows that females ingest, on average, 14 and $8.5 \mu \mathrm{g} \mathrm{C}$ $\mathrm{d}^{-1}$ in spring and autumn, respectively. While the spring estimate is similar to the figure mentioned above, the autumn estimate is lower. The low number of males and spermatophores in autumn might explain the low SEP in autumn. Females may not be fertilised and SEP may not reflect food intake. Furthermore, egg-production might be relatively uncoupled to ingestion since Pareuchaeta norvegica accumulates lipids. Several studies have shown that egg production is supported by lipid reserves in the species (Bakke 1977, Båmstedt 1979, Hopkins 1982).

The predation impact on the ambient copepod prey populations was calculated at 2 stations, T3 and T4, in the following way: Predation (feeding rate) by CIV and CV copepodites (Fig. 7) expressed as prey $\mathrm{d}^{-1}$ was taken to represent all copepodites (CI-CV). We then used the relationship between optimal prey size and prosome length suggested by Yen (1985): optimal prey size is $70 \%$ of the length of the second basipodal segment of the maxilliped or $20 \%$ of prosome length. Using the size distribution of Pareuchaeta norvegica and the copepod prey community, a subset of the prey community was defined as available for the predators. Predation impact was then calculated based on feeding rates (Fig. 7), P. norvegica abundance (Fig. 2) and prey abundance (Table 2). We only have data from daytime sampling and used averages from 0 to $25 \mathrm{~m}$ for calculations. This was performed at each station separately and expressed as percent of copepod abundance ingested per day.

In spring, daily predation impact on small copepods was 4.6 (Stn T3) and 2.0\% (Stn T4). These rates can be compared with estimates of predation by the chaetog- nath Sagitta elegans from the same survey in spring (K. Tönnesson unpubl. data). The abundance of $S$. elegans ranged from 0.5 to 3 ind. $\mathrm{m}^{-3}$ and showed no spatial pattern, which is similar to the figure of 0.4 to 0.8 ind. $\mathrm{m}^{-3}$ found by Båmstedt (1985) in the Skagerrak. The number of prey in Sagitta elegans guts ranged from 0.7 to 1.2 prey ind. ${ }^{-1}$ and the gut evacuation rate was $0.15 \mathrm{~h}^{-1}$. For $S$. elegans, the daily predation rate $(0$ to $25 \mathrm{~m}$ ) was on average $0.07 \% \mathrm{~d}^{-1}$ at Stn T3 and T4, which is 30 to 65 times lower than the rates for Pareuchaeta norvegica. It can be noted that evacuation rates are considerably lower in $P$. norvegica, but gut content much higher compared to $S$. elegans. The typical number of prey in $S$. elegans was 0.85 prey ind. ${ }^{-1}$ compared to 6 to 11 prey ind.$^{-1}$ for $P$. norvegica copepodites, whereas the evacuation rate for $S$. elegans at $5^{\circ} \mathrm{C}$ is $0.15 \mathrm{~h}^{-1}$ (Ohman 1986) compared to $0.048 \mathrm{~h}^{-1}$ for $P$. norvegica. Comparing these 2 important invertebrate predators, the daily predation impact on the ambient copepod community in spring was entirely dominated by $P$. norvegica.

In autumn, the daily predation impact of Pareuchaeta norvegica was $2.4 \%$ at Stn T3 and $6.5 \%$ at Stn T4. We did not measure predation impact of chaetognaths in autumn, but we can estimate a potential impact from data on abundance for this. We used the number of prey found in Sagitta elegans guts for the same season in the Gullmar fjord (Tönnesson \& Tiselius 2005), a gut evacuation rate of $0.23 \mathrm{~h}^{-1}\left(10^{\circ} \mathrm{C}\right)$ and the observed abundances of chaetognaths in this study (K. Tönnesson unpubl. data). The predation impact of chaetognaths was $0.44 \%$ at Stn T3 and $0.06 \%$ at Stn T4, which is 5 to 108 times lower than the impact of $P$. norvegica. The predation is in accordance with previous reports on other invertebrate predators (Stuart \& Verheye 1991, Drits \& Utkina 1988), even though much higher rates have been reported (e.g. Kimmerer 1984, Tönnesson \& Tiselius 2005). There might be an underestimation of the predation impact of chaetognaths in the autumn because the recorded abundances in the pump samples were very low (1 to 2 ind. $\mathrm{m}^{-3}$ ). Parallel sampling with a WP-2 net showed a 10-fold higher abundance than sampling with a pump (Stn T2). For comparison, chaetognath abundance in August to September in the Gullmar fjord ranged from 20 to 150 ind. $\mathrm{m}^{-3}$, consisting mostly of the smaller $S$. setosa, but still with a similar prey preference size range as $P$. norvegica.

The impact on prey production may be even higher. The mean weight-specific egg production rate (SEP) for small copepods in spring was low $\left(5 \% \mathrm{~d}^{-1}\right.$, Maar et al. 2002) and the weight-based predation impact of Pareuchaeta norvegica ranged from 0.3 to $0.7 \% \mathrm{~d}^{-1}$, which is 6 to $14 \%$ of copepod production, if female egg production is representative of copepod population 
production. In autumn, mean $S E P$ for small copepods was $10.8 \% \mathrm{~d}^{-1}$ (Maar et al. 2004) and the predation impact was 1 to $1.7 \% \mathrm{~d}^{-1}$, which equals 9 to $16 \%$ of the copepod population production.

The present study documents that invertebrate predation is an important regulating factor for populations of small copepods. The well-investigated chaetognaths are often considered to be dominant predators, but the impact of Pareuchaeta norvegica exceeded chaetognath predation 10- to 100 -fold in spring and autumn. Our estimate of predation impact is based on daytime vertical distributions and may be considered a conservative estimate. If migration from deeper waters $(>100 \mathrm{~m})$ occurred, there could be a substantially higher predation. Strong predation should have an impact on the abundance of prey copepods and $P$. norvegica was also most abundant in the transect stations T2 to T4. Stn T2 has previously been reported to have a high biomass of $P$. norvegica (Tiselius 1988). In May 1987, a biomass of $23 \mathrm{mg} \mathrm{C} \mathrm{m}^{-3}$ of $P$. norvegica was found in the upper $15 \mathrm{~m}$ at night. This is similar to the $26 \mathrm{mg} \mathrm{C} \mathrm{m}^{-3}$ found at Stn T2 at night in autumn in the present study. Interestingly, Tiselius (1988) found very few small copepods at Stn T2, an observation that could be caused by strong top-down control by the high biomass of $P$. norvegica. The population dynamics of this key invertebrate predator are not well known and deserve further investigation.

Acknowledgements. This study was supported by ECMAST3 project KEYCOP (MAST III: MAS3-CT97-0148) and CREAM (Centre for Research and Monitoring of the Marine Environment) at the National Environmental Research Institute in Roskilde, Denmark to K.T., and by the Danish Natural Science Research Council Grant \# 9801391 to T.G.N. We are grateful to P. Greve at Roskilde University Centre for assistance with carbon analyses and for the technical assistance of the crew of R/V 'Dana'. Comments from S. Kaartvedt and 4 anonymous reviewers improved the paper.

\section{LITERATURE CITED}

Alonzo F, Mayzaud P, Razouls S (2000) Egg-production dynamics, biochemical composition and hatching success of the subantarctic copepod Pareuchaeta antarctica: laboratory studies. Mar Ecol Prog Ser 205:219-227

Alvarez V, Matthews JBL (1975) Experimental studies on the deep-water pelagic community of Korsfjorden, western Norway. Feeding and assimilation by Chiridus armatus (Crustacea, Copepoda). Sarsia 58:67-78

Bagøien E (1999) Predatory impact of invertebrates and fish on overwintering Calanus. PhD thesis, University of Oslo

Bakke JLW (1977) Ecological studies on the deepwater pelagic community of Korsfjorden, western Norway. Population dynamics of Euchaeta norvegica (Crustacea, Copepoda) from 1971 to 1974. Sarsia 63:49-55

Båmstedt U (1979) Reproductive bioenergetics within the summer and winter generations of Euchaeta norvegica (Copepoda). Mar Biol 54:135-142
Båmstedt U (1985) Spring-bloom dynamics in Kosterfjorden, western Sweden: variation in phytoplankton production and macrozooplankton characteristics. Sarsia 70:69-82

Båmstedt U, Holt MR (1978) Experimental studies on the deep-water pelagic community of Korsfjorden, western Norway. Prey-size preference and feeding of Euchaeta norvegica (Copepoda) in relation to its life cycle. Sarsia 63: $225-236$

Bathmann UV, Noji TT, von Bodungen B (1990) Copepod grazing potential in late winter in the Norwegian Sea-a factor in the control of spring phytoplankton growth? Mar Ecol Prog Ser 60:225-233

Corner EDS, Head RN, Kilvington CC, Pennywick L (1976) On the nutrition and metabolism of zooplankton. X. Quantitative aspects of Calanus helgolandicus feeding as a carnivore. J Mar Biol Assoc UK 56:345-358

Dale T, Bagøien E, Melle W, Kaartvedt S (1999) Can predator avoidance explain varying overwintering depth of Calanus in different oceanic water masses? Mar Ecol Prog Ser 179:113-121

Drits AV, Utkina SV (1988) Feeding of Sagitta setosa in the layers of daytime phytoplankton accumulation in the Black Sea. Oceanology 28:781-785

Edmondson WT (1971) Reproductive rates determined directly from egg ratio. In: Edmondson WT, Winberg GG (eds) A manual on methods for assessment of secondary production in fresh waters. Blackwell Scientific, Oxford, p 165-169

Gauld DT (1953) Diurnal variations in the grazing of planktonic copepods. J Mar Biol Assoc UK 31:461-474

González, HE, González, SR, Brummer, GA (1994) Short-term sedimentation pattern of zooplankton, feces and microplankton at a permanent station in the Bjørnafjorden (Norway) during April-May 1992. Mar Ecol Prog Ser 105:31-45

Greene CH (1988) Foraging tactics and prey-selection patterns of omnivorous and carnivorous calanoid copepods. Hydrobiologica 167/168:295-302

Greene CH, Landry MR (1985) Patterns of prey selection in the cruising calanoid predator Euchaeta elongata. Ecology 66:1408-1416

Hopkins CCE (1977) The relationship between maternal body size and clutch size, development time and egg mortality in Euchaeta norvegica (Copepoda: Calanoida) from Loch Etive, Scotland. J Mar Biol Assoc UK 57:723-733

Hopkins CCE (1982) The breeding biology of Euchatea norvegica (Boeck) (Copepoda: Calanoida) in Loch Etive, Scotland: assessment of breeding intensity in terms of seasonal cycles in the sex ratio, spermatophore attachment, and egg-sac production. J Exp Mar Biol Ecol 60:91-102

Hopkins CCE, Machin D (1977) Patterns of spermatophore distribution and placement in Euchaeta norvegica (Copepoda: Calanoida). J Mar Biol Assoc UK 57:113-131

Kaartvedt S, Dale T, Bagøien E, Viken T (2002) Bi-modal vertical distribution of the carnivorous copepod Pareuchaeta norvegica. J Plankton Res 24:155-158

Katona SK (1975) Copulation in the copepod Eurytemora affinis (Poppe, 1880). Crustaceana 28:89-95

Kiørboe T, Sabatini M (1995) Scaling of fecundity, growth and development in marine planktonic copepods. Mar Ecol Prog Ser 120:285-298

Kimmerer WJ (1984) Selective predation and its impact on prey of Sagitta enflata (Chaetognatha). Mar Ecol Prog Ser 15:55-62

Lowndes AG (1935) The swimming and feeding of certain calanoid copepods. Proc Zool Soc Lond 687-715

Maar M, Nielsen TG, Richardson K, Christaki U, Hansen OS, Zervoudaki S, Christou ED (2002) Spatial and temporal 
variability of food web structure during the spring bloom in the Skagerrak. Mar Ecol Prog Ser 239:11-29

Maar M, Nielsen TG, Gooding S, Tönnesson K and 5 others (2004) The trophodynamic function of copepods, appendicularians and protozooplankton in the late summer zooplankton community in the Skagerrak. Mar Biol 144: 917-933

Mackas D, Bohrer R (1976) Fluorescence analysis of zooplankton gut contents and an investigation of diel feeding patterns. J Exp Mar Biol Ecol 25:77-85

Mauchline J (1994) Spermatophore transfer in Euchaeta species in a $2000 \mathrm{~m}$ water column. Hydrobiologia 292/293: 309-316

Mauchline J (1998) The biology of calanoid copepods. Adv Mar Biol 33, Academic Press, London, p 1-701

Nemoto T, Mauchline J, Kamada K (1976) Brood size and chemical composition of Pareuchaeta norvegica (Crustacea: Copepoda) in Loch Etive, Scotland. Mar Biol 36: 151-157

Nielsen TG, Møller EF, Satapoomin S, Ringuette M, Hopcroft RR (2002) Egg hatching rate of the cyclopoid copepod Oithona similis in arctic and temperate waters. Mar Ecol Prog Ser 236:301-306

Ohman MD (1986) Predator-limited population growth of the copepod Pseudocalanus sp. J Plankton Res 8:673-713

Olsen EM, Jørstad T, Kaartvedt S (2000) The feeding strategies of two large marine copepods. J Plankton Res 22: $1513-1528$

Øresland V (1990) Feeding and predation impact of the chaetognath Eukrohina hamata in Gerlache Strait, Antarctic Peninsular. Mar Ecol Prog Ser 63:201-209

Øresland V (1991) Feeding of the carnivorous copepod Euchaeta antarctica in Antarctic waters. Mar Ecol Prog Ser 78:41-47

Øresland V, Ward P (1993) Summer and winter diet of four carnivorous copepod species around South Georgia. Mar Ecol Prog Ser 98:73-78

Park T (1995) Geographic-distribution of the bathypelagic genus Pareuchaeta (Copepoda, Calanoida). Hydrobiologica 293:317-332

Skarra H, Kaartvedt S (2003) Vertical distribution and feeding

Editorial responsibility: Howard I. Browman (Associate Editor-in-Chief), Storebø, Norway of the carnivorous copepod Pareuchaeta norvegica. Mar Ecol Prog Ser 249:215-222

Stuart V, Verheye HM (1991) Diel migration and feeding patterns of the chaetognath, Sagitta friderici, off the west coast of South Africa. J Mar Res 49:493-515

Tiselius P (1988) Effects of diurnal feeding rhythms, species composition and vertical migration on the grazing impact of calanoid copepods in the Skagerrak and Kattegat. Ophelia 28(3):215-230

Tiselius P, Jonsson P, Kaartvedt S, Olsen ME, Jørstad T (1997) Effects of foraging behavior on predation risk: an experimental study of the predatory copepod Pareuchaeta norvegica feeding on Acartia clausi and A. tonsa. Limnol Oceanogr 42:164-170

Tönnesson K, Tiselius P (2005) Diet of the chaetognaths Sagitta setosa and $S$. elegans in relation to prey abundance and vertical distribution. Mar Ecol Prog Ser 289: 177-190

Ward P, Robins DB (1987). The reproductive biology of Euchaeta antarctica Giesbrecht (Copepoda: Calanoida) at South Georgia. J Exp Mar Biol Ecol 108:127-145

Yen J (1982a) Sources of variability in attack rates of Euchaeta elongata Esterly, a carnivorous copepod. J Exp Mar Biol Ecol 63:105-117

Yen J (1982b) Effects of prey concentration, prey size, predator life stage, predator starvation, and season on predation rates of the carnivorous copepod Euchaeta elongata. Mar Biol 75:69-77

Yen J (1985) Selective predation by the carnivorous marine copepod Euchaeta elongata: laboratory measurements of predation rates verified by field observations of temporal and spatial feeding patterns. Limnol Oceanogr 30:577-597

Yen J (1987) Predation by Euchaeta norvegica Boeck on eggs and larvae of the Atlantic cod Gadus morhua L. J Exp Mar Biol Ecol 112:283-296

Yen J (1988) Directionally and swimming speeds in predatoprey and male-female interactions of Euchaeta rimana, a subtropical marine copepod. B Mar Sci 43:395-403

Yen J (1991) Predatory feeding behavior of an Antarctic marine copepod, Euchaeta antarctica. Polar Res 10: 433-442

Submitted: June 16, 2005; Accepted: November 5, 2005

Proofs received from author(s): April 12, 2006 